\title{
Pengaruh Pengungkapan Corporate Social Responsibility, Investment Opportunity Set dan Struktur Modal pada Nilai Perusahaan
}

\author{
Kadek Dina Sabina Rini ${ }^{1}$ \\ Fakultas Ekonomi dan Bisnis \\ Universitas Udayana, Indonesia. \\ Email: dina.sabinarini@gmail.com
}

\author{
Ni Putu Sri Harta Mimba ${ }^{2}$ \\ Fakultas Ekonomi dan Bisnis \\ Universitas Udayana, Indonesia.
}

\begin{abstract}
ABSTRAK
Sampel yang digunakan dalam penelitian ini sebanyak 28 perusahaan sehingga didapat 140 amatan. Sampel penelitian diambil dengan menggunakan teknik purposive sampling. Teknik analisis yang digunakan dalam penelitian ini adalah regresi linear berganda. Hasil dari penelitian ini menunjukkan bahwa pengungkapan corporate social responsibility berpengaruh positif pada nilai perusahaan. Investment opportunity set berpengaruh positif pada nilai perusahaan. Struktur modal berpengaruh positif pada nilai perusahaan. Implikasi teoritis penelitian menunjukkan hasil penelitian sejalan dengan teori sinyal. Implikasi praktis penelitian dapat menjadi bahan pertimbanganbagi investor dalam mengambil keputusan dengan melihatinformasi pengungkapan CSR, IOS dan Struktur Modal perusahaan.
\end{abstract}

Kata Kunci : Nilai Perusahaan, corporate social responsibility, investment opportunity set, struktur modal.

\section{Effects of Corporate Social Responsibility Disclosure, Investment Opportunity Set and Capital Structure on Company Value}

\section{ABSTRACT}

The samples used in this study were 28 companies so that there were 140 observations. The research sample was taken using purposive sampling technique. The analysis technique used in this study is multiple linear regression. The results of this study indicate that the disclosure variables of corporate social responsibility have a positive effect on firm value. The variable investment opportunity set has a positive effect on firm value. Capital structure variables have a positive effect on firm value. Theoretical implications of the research show that the results of the research are in line with signal theory. The practical implications of research can be taken into consideration for investors in making decisions by looking at information on CSR disclosures, IOS and company capital structure.

Keywords: Corporate value, corporate social responsibility, investment opportunity set, capital structure.

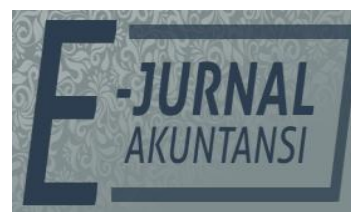

E-JA

e-Jurnal Akuntansi e-ISSN 2302-8556

Denpasar,

Vol. 28 No. 3

September 2019

Hal. 2019-2034

Artikel masuk:

28 Juni 2019

Tanggal diterima: 02 September 2019 


\section{PENDAHULUAN}

Perusahaan ketika didirikan memiliki tujuan yang ingin dicapai. Tujuan perusahaan tersebut berhubungan dengan perusahaan itu sendiri maupun pendiri perusahaan. Tujuan yang umumnya ingin dicapai perusahaan adalah menghasilkan laba yang maksimal serta memaksimalkan nilai perusahaan. Tujuan perusahaan untuk pendiri perusahaan maupun pemegang saham perusahaan adalah memberi kemakmuran bagi pendiri dan pemegang saham (Syardiana, 2015).

Disebutkan bahwa memaksimalkan nilai perusahaan merupakan salah satu tujuan perusahaan. Ketika suatu perusahaan perusahaan dijual, dan calon pembeli bersedia untuk membayar sejumlah harga, harga yang dibayarkann tersebut merupakan nilai perusahaan. Nilai perusahaan berisikan pandangan dari investor terhadap pengelolaan perusahaan dan bagaimana kinerja manajemen dalam menjalankan fungsi manajemen dari awal perusahaan didirikan hingga masa kini (Li, 2017). Harga saham dari suatu perusahaan merupakan cerminan dari nilai perusahaan tersebut. Hal ini merupakan informasi yang dapat dijadikan sebagai salah satu bahan pertimbangan oleh calon investor dalam mengambil keputusan karena harga saham suatu perusahaan merupakan alat ukur untuk mengetahui citra dari perusahaan bagi publik(Bella \& Suaryana, 2017).

Proses terbentuknya harga saham tergantung dari permintaan dan penawaran dari investor oleh karena itu harga saham dipilih sebagai proksi dari nilai perusahaan(Noerirawan \& Muid, 2012). Banyaknya permintaan investor atas saham dari perusahaan tertentu akan berdampak terhadap harga saham perusahaan yaitu terjadinya peningkatan harga saham perusahaan tersebut.

Berkembangnya sektor properti dan real estatediakibatkan salah satunya dari berkembangnya tren masyarakat dalam berinvestasi yang kini banyak masyarakat memilih tanah atau properti sebagai bentuk dari investasi. Peluang yang dihasilkan dari berkembangnya tren investasi tanah dan properti ini dilihat oleh banyak perusaahaan dan banyak yang memanfaatkan peluang ini (Hamidyet al., 2015). Perusahaan-perusahaan berlomba-lomba untuk memaksimalkan nilai perusahaan agar menarik minat investor untuk berinvestasi diperusahaannya.

Nilai perusahaan tidaklah selalu mengalami peningkatan, terkadang penurunan nilai perusahaan dapat terjadi. Seperti fenomena yang terjadi yaitu tercatat sejak akhir Mei 2013, indeks saham sektor properti telah merosot hingga 37,75 persen. Indeks saham sektor properti bertengger di 351,89 . Penurunan indeks saham sektor properti itu lebih dalam ketimbang Indeks Harga Saham Gabungan (IHSG). Di periode sama, IHSG tercatat turun 13,22 persen (Investasi.kontan.co.id.). Pada awal Tahun 2017 indeks sektor properti terjun bebas Pada Januari, indeks sektor berada di level 521,547. Artinya, indeks sektor properti melorot sebesar 5,67 persen. PT Pakuwon Jati Tbk (PWON) turun 2,4 persen ke level Rp 610 per saham. Penurunan juga terjadi pada saham PT Metropolitan Kentjana Tbk (MKPI) hingga 3,16 persen di level Rp 24.500 per saham dan PT Jaya Real Property Tbk 1,19 persen ke level Rp825 per saham. Sementara, Summarecon Agung bergerak stagnan di level Rp 1.210 per saham.(cnnindonesia.com). 
Nilai perusahaan dapat dipengaruhi oleh salah satunya Corporate Social Responsibility atau CSR. CSR wajib untuk diungkapkan berdasarkan teori stakeholders dan pengungkapan ini dapat berdampak positif pada nilai perusahaan ( $\mathrm{Li}, 2017)$. Bentuk tanggung jawab perusahaan kepada ekonomi perusahaan, karyawan dan lingkungan sekitar merupakan aktivitas utama dari CSR. Tanggung jawab perusahaan terhadap karyawan dapat diwujudkan dengan meningkatkan kualitas hidup dari karyawan perusahaan. Tanggung jawab perusahaan terhadap lingkungan sekitar dapat diwujudkan salah satunya dengan meningkatkan kualitas hidup dari masyarakat sekitar perusahaan tersebut beroperasi. Image perusahaan cenderung akan mengalami peningkatan dengan semakin banyaknya aktivitas CSR yang dilakukan oleh perusahaan. Peningkatan pada citra perusahaan ini merupakan pandangan positif yang didapat oleh perusahaan atas segala pertanggungjawaban yang dilakukan oleh perusahaan. Ketika citra perusahaan mengalami peningkatan, loyalitas dari konsumen akan mengalami peningkatan juga (Sihotang, 2018).

Paradigma baru perusahaan mengenai kondisi keuangan perusahaan yang diukur dengan pencapaian laba dianggap tidak cukup memiliki jaminan bahwa nilai perusahaan akan tumbuh dan berkelanjutan. Tanggung jawab perusahaan diharapkan tidak hanya berfokus pada single bottom line melainkan juga fokus pada triple bottom line. Aktivitas CSR kini telah dianggap sebagai investasi oleh perusahaan dan bukan lagi sebagaicost, hal ini karena perusahaan melihat bagaimana penerapan CSR semakin penting bagi suatu perusahaan (Fajriana, 2016). Terdapat beberapa penelitian sebelumnya mengenai hubungan antara CSR pada nilai perusahaan yang dilakukan oleh Permana \& Wirawati (2018), Bella \& Suaryana (2017) dan Li (2017) dan dari ketiga penelitian sebelumnya mendapatkan hasil yang serupa yaitu terdapat pengaruh positif antara CSR pada nilai perusahaan. Namun berbeda dengan hasil yang didapatkan oleh Inastri \& Mimba (2017) dalam penelitiannya yaitu CSR memiliki pengaruh yang negatif serta tidak signifikan pada nilai perusahaan.

IOS atau investment opportunity set berhubungan dengan studi mengenai keputusan investasi (Fajriana, 2016). Penilaian terhadap perusahaan oleh pihak internal maupun eksternal dipengaruhi oleh IOS (Kallapur \& Trombley, 2001). Rencana pengeluaran manjemen untuk masa depan serta pengeluaran manajemen saat masa sekarang diharapkan memiliki pengembalian yang lebih tinggi dari modal yang dikeluarkan oleh manajemen. Hal ini mempengaruhi nilai IOS perusahaan (Kole, 1991).

Penelitian sebelumnya dilakukan oleh Senda (2013), Hariyanto \& Lestari (2015), Hamidah \& Umdiana (2017)dan Syardiana (2015)yang mengangkat topik IOS dan nilai perusahaan. Hasil yang didapatkan dari penelitian tersebut adalah adanya pengaruh positif dari IOS pada nilai perusahaan. Hasil ini memiliki arti bahwa pertambahan kekayaan atau aset pada perusahaan cenderung terjadi pada perusahaan yang melakukan banyak investasi. Kekayaan yang semakin bertambah memicu terjadinya perkembangan pada perusahaan kearah yang positif. perkembangan-perkembangan ini dilihat oleh investor sebagai sinyal yang baik. Investor telah memiliki pandangan yang positif pada perusahaan yang terus mengalami perkembangan sehingga berdampak pada banyaknya permintaan pada saham perusahaan tersebut. Banyaknya permintaan pada 
saham perusahaan kemudian akan berdampak pada naiknya harga saham yang berarti akan terjadi peningkatan pada nilai perusahaan. Kebon \& Suryanawa(2017)mendapatkan hasil yang berbeda hasil yang didapatkan dalam peneitian yang dilakukannya yaitu IOS tidak memiliki pengaruh pada nilai perusahaan.

Faktor lainnya yang dapat mempengaruhi nilai perusahaan adalah struktur modal. Untuk mendapatkan nilai perusahaan yang maksimal struktur modal perusahaan perlu dioptimalkan. Setiap bisnis perlu menentukan struktur modalnya. Dalam penentuan struktur modal perlu diperhatikan efek positif dan negative yang mungkin terjadi dalam keputusan yang diambil yang akan berdampak pada masa depan bisnis tersebut (Fumani \& Moghadam, 2015). Manajemen menyadari bahwa biaya modal yang minimum dapat meningkatkan nilai perusahaan(Antwi et al., 2012).

Struktur modal merupakan perbandingan antara utang jangka pendek, utang jangka panjang, saham preferen dan saham biasa (Sartono, 2012). Penelitian yang berhubungan dengan struktur modal diantaranya adalah penelitian yang dilakukan oleh Cuong (2014), Suweta \& Dewi (2016), Hermuningsih (2013), Isaac (2014), Asif \& Aziz (2016), Riaz \& Qasi (2016) serta Zeb \& Rashid (2016). Hasil yang didapatkan dalam penelitian sebelumnya yang dilakukan adalah terdapat pengaruh positif dari struktur modal pada nilai perusahaan. Dewi \& Wirajaya (2013), Situmeang \& Wiagustini (2018)menemukan hasil yang berbeda dari penelitian yang dilakukannya yaitu struktur modal memiliki pengaruh negatif padanilai perusahaan.

Perusahaan memberikan informasi kepada orang-orang yang memerlukan informasi tersebut. Informasi tersebut digunakan untuk pertimbangan dalam memutuskan keputusan informasi. Pemberian informasi oleh manajemen perusahaan dan hubungannya pada keputusan investasi pihak eksternal ini disebut dengan teori sinyal signalling theory. Informasi yang diperlukan pihak eksternal adalah informasi yang terutama memiliki histori keadaan keuangan perusahaan yang kemudian dapat dijadikan pertimbangan dalam pengambilan keputusan.Teori sinyal dicetuskan pertama kali oleh Spence (1973) dalam penelitiannya yang berjudul Job Market Signalling. Teori ini melibatkan dua pihak, yakni pihak dalam seperti manajemen yang berperan sebagai pihak yang memberikan sinyal dan pihak luar seperti investor yang berperan sebagai pihak yang menerima sinyal tersebut. Spence mengatakan bahwa dengan memberikan suatu isyarat atau sinyal, pihak manejemen berusaha memberikan informasi yang relevan yang dapat dimanfaatkan oleh pihak investor. Kemudian, pihak investor akan menyesuaikan keputusannya sesuai dengan pemahamannya terhadap sinyal tersebut.

Perusahaan mempublikasikan informasi-informasi perusahaan yang kemudian menjadi sinyal bagi para investor. Sinyal ini akan digunakan oleh investor sebagai bahan pertimbangan dalam pengambilan keputusan investasi (Jogiyanto, 2007). ketika informasi dipublikasikan hingga akhirnya diterima oleh pelaku pasar makainformasi yang dipublikasikan tersebut terlebih dahulu diinterpretasikan dan dianalisis sebagai sinyal baik (good news) atau sinyal buruk (bad news). Jika informasi yang diumumkan tersebut sebagai sinyal baik bagi investor, selanjutnya akan terjadi perubahan volume perdagangan saham yang 
mampumeningkatkan harga saham. Harga saham yang meningkat tersebut juga akan meningkatkan nilai perusahaan.Hubungan teori sinyal dengan penelitian pada perusahaan properti dan real estate ini menunjukkan bahwa manajemen menggunakan pengungkapan corporate social responsibility, investment opportunity set dan struktur modal untuk memberikan sinyal kepada investor mengenai nilai perusahaan. Investor akan menganggap pengungkapan corporate social responsibility, investment opportunity set dan struktur modal merupakan sinyal positif yang menentukan nilai perusahaan properti dan real estate.

Dalam suatu perusahaan terdapat pihak internal maupun eksternal yang keberadaannya memiliki pengaruh yang cukup besar terhadap perusahaan. Pihak-pihak tersebut disebut dengan stakeholder (Hadi, 2011). Berdasrkan teori stakeholder, diharapkan dengan dengan adanya pengungkapan tanggung jawab sosial perusahaan diharapkan agar perusahaan mampu untuk mengelola informasi para stakeholder, sehingga dukungan stakeholder juga terpenuhi dalam menunjang keberlangsungan perusahaan.

Komitmen sektor swasta untuk mendukung terciptanya pembangunan yang berkelanjutan (sustainable development) salah satunya adalah Corporate Social Responsibility dikutip dari World Bank(Foxet al., 2002). Bentuk tanggung jawab perusahaan kepada ekonomi perusahaan, kryawan dan lingkungan sekitar merupakan aktivitas utama dari CSR. Tanggung jawab perusahaan terhadap karyawan dapat diwujudkan dengan meningkatkan kualitas hidup dari karyawan perusahaan. Tanggung jawab perusahaan terhadap lingkungan sekitar dapat diwujudkan salah satunya dengan meningkatkan kualitas hidup dari masyarakat sekitar perusahaan tersebut beroperasi.

Istilah Investment Opportunity Set(IOS) dikemukakan oleh Myers, (1977)dalam Hidayah (2015)yang memandang nilai suatu perusahaan sebagai sebuah kombinasi aktiva yang dimiliki (asssets in place) dan pilihan investasi di masa yang akan datang dengan net present value positif. IOS menghasilkan net present value. Respon investor dapat berubah sesuai dengan net present valueyang dihasilkan oleh IOS perusahaan. Ketika IOS menghasilkan net present valueyang baik atau positif, respon positif cenderung akan didapatkan oleh perusahaan begitu juga sebaliknya. Hal tersebut akan berpengaruh terhadap harga saham dan nilai perusahaan tersebut.Rencana pengeluaran manjemen untuk masa depanserta pengeluaran manajemen pada masa sekarang diharapkan memiliki pengembalian yang lebih tinggi dari modal yang dikeluarkan oleh manajemen. Hal ini mempengaruhi nilai IOS perusahaan (Kole, 1991).

Struktur modal adalah pembiayaan permanen yang terdiri dari hutang jangka panjang, saham preferen dan modal pemegang saham (Weston \& Copeland., 2008). Struktur modal merupakan kumpulan dana yang dapat digunakan untuk dialokasikan oleh perusahaan (Lubis, 2017). Struktur modal juga dapat diartikan sebagai perimbangan atau perbandingan antara jumlah hutang jangka panjang dengan modal sendiri. Perusahaan yang memilih utang sebagai sumber dana eksternalnya mengetahui betul sisi positif maupun negatif dari keputusan tersebut. Sisi positif yang dirasakan perusahaan adalah pada sisi pajak dimana bunga hutang merupakan pengurangan pada pajak selain itu dengan memiliki utang manajemen akan terlatih untuk memenuhi kewajiban tersebut secara disiplin sehingga akan terbentuknya manajemen dengan disiplin 
yang tinggi. Sisi negatif yang dirasakan oleh perusahaan adalah pada sisi munculnya biaya keagenan serta biaya kepailitan (Syardiana, 2015).

Teori trade-off memprediksi hubungan positif antara struktur modal dengan nilai perusahaan dengan asumsi keuntungan pajak masih lebih besar dari biaya tekanan financial dan biaya keagenan (Sari, 2017).

Menurut Fuad (2000) nilai perusahaan merupakan harga jual perusahaan yang dianggap layak oleh calon investor jika suatu saat perusahaan akan dijual. Nilai perusahaan berisikan pandangan dari investor terhadap pengelolaan perusahaan dan bagaimana kinerja manajemen dalam menjalankan fungsi manajemen dari awal perusahaan didirikan hingga masa kini (Li, 2017). Harga saham dari suatu perusahaan merupakan cerminan dari nilai perusahaan tersebut. Hal ini merupakan informasi yang dapat dijadikan sebagai salah satu bahan pertimbangan oleh calon investor dalam mengambil keputusan karena harga saham suatu perusahaan merupakan alat ukur untuk mengetahui citra dari perusahaan bagi public (Bella \& Suaryana, 2017).

Memaksimalkan nilai suatu perusahaan merupakan salah satu tujuan perusahaan dimana nilai perusahaan yang tinggi dapat meningkatkan kemakmuran bagi pemegang saham dan menjadi bahan pertimbangan para pemegang saham yang akan menginvestasikan modalnya kepada perusahaan tersebut. Perusahaan yang telah menerapkan CSR pada umumnya akan mengungkapkan pelaksanaan CSR tersebut karena pengungkapan CSR yang dilakukan oleh perusahaan dapat memberikan sinyal positif tentang pertumbuhan perusahaan di masa yang akan datang, sehingga dapat meningkatkan nilai perusahaan. Berdasarkan signalling theory yaitu dengan memberikan sinyal positif berupa informasi terkait CSR diharapkan bukan hanya dapat mengurangi asimetri informasi antara manajemen dengan stakeholders namun juga dapat meningkatkan kepercayaan stakeholders pada perusahaan sehingga bukan hanya dapat meningkatkan reputasi atau citra perusahaan namun juga dapat meningkatkan minat masyarakat untuk berinvestasi (Anjani \& Astika, 2018).

Penelitian yang dilakukan oleh Fajriana (2016), Bella \& Suaryana (2017) diperoleh hasil bahwa pengungkapan CSR berpengaruh positif pada nilai perusahaan, pernyataan ini diperkuat oleh penelitian yang dilakukan oleh Permana \& Wirawati (2018), Jitmaneeroj (2018)juga mengungkapkan bahwa CSR berpengaruh positif pada nilai perusahaan. Berdasarkan uraian di atas maka hipotesis penelitian dapat dirumuskan sebagai berikut:

$\mathrm{H}_{1}$ : Pengungkapan Corporate Social Responsibility (CSR) berpengaruh positif pada nilai perusahaan.

IOS atau investment opportunity set berhubungan dengan studi mengenai keputusan investasi (Fajriana, 2016). Penilaian terhadap perusahaan oleh pihak internal maupun eksternal dipengaruhi oleh IOS (Kallapur \& Trombley, 2001). Rencana pengeluaran manjemen untuk masa depan serta pengeluaran manajemen saat masa sekarang diharapkan memiliki pengembalian yang lebih tinggi dari modal yang dikeluarkan oleh manajemen. Hal ini mempengaruhi nilai IOS perusahaan (Kole, 1991).

Penelitian sebelumnyaSenda (2013), Hariyanto \& Lestari (2015), Hamidah \& Umdiana (2017) dan Syardiana (2015) yang mengangkat topik IOS dan nilai 
perusahaan. Hasil yang didapatkan dari penelitian tersebut adalah adanya pengaruh positif dari IOS pada nilai perusahaan.

$\mathrm{H}_{2}$ : Investment Opportunity Set (IOS) berpengaruh positif pada nilai perusahaan.

Teori Trade off penggunaan utang yang semakin banyak oleh perusahaan, maka akan semakin tinggi harga saham perusahaan pada target struktur modal yang optimal. Hal ini berarti jika struktur modal berada dibawah nilai target optimal, nilai perusahaan akan meningkat setiap terjadinya penambahan utang (Situmeang \& Wiagustini 2018). Kebijakan struktur modal melibatkan perimbangan (trade off) anatara risiko dan tingkat pengembalian.

Teori sinyalyang menyatakan bahwa adanya sinyal peningkatan jumlah utang dalam struktur modal suatu perusahaan mengindikasikan bahwa perusahaan merasa yakin akan prospek perusahaan di masa yang akan datang sehingga perusahaan tidak khawatir dengan pembayaran utang dan bunganya (Pratama \& Putu, 2016). Struktur modal yang optimal harus berada pada keseimbangan antara risiko dan pengembalian yang memaksimumkan harga saham (Brigham \& Houston, 2011).Oleh karena itu, dengan asumsi titik target struktur modal optimal belum tercapai, maka berdasarkan trade-off theory memprediksi adanya hubungan yang positif terhadap nilai perusahaan. Dewi et al. (2014), Asif \& Aziz (2016), Zeb \& Rashid (2016)serta Indasari \& Yadnyana (2018) menemukan bahwa struktur modal memiliki pengaruh positif terhadap nilai perusahaan.

$\mathrm{H}_{3}$ : Struktur Modal berpengaruh positif pada nilai perusahaan.

\section{METODE PENELITIAN}

Penelitian ini dilakukan pada perusahaan properti dan real estateyang terdaftar di Bursa Efek Indonesia (BEI) tahun 2013-2017 web resmi dari BEI yaitu www.idx.co.id menjadi sumber pencarian data dan juga website perusahaan.Nilai perusahaan adalah objek penelitian ini.

CSR adalah media komunikasi perusahaan dengan masyarakat tentang aktivitas yang dilakukan perusahaan dan berhubungan dengan tanggung jawab sosial perusahaan.Pengungkapan CSR diukur menggunakan proksi Corporate Social Responsbility Disclosure Index (CSRDI) berdasarkan indicator GRI G.4. Pemberian skor 1 dan 0 untuk mengungkapkan dan tidak mengungkapkan CSR merupakan penilaian untuk CSR.

IOS atau investment opportunity set berhubungan dengan studi mengenai keputusan investasi (Fajriana, 2016). Penilaian terhadap perusahaan oleh pihak internal maupun eksternal dipengaruhi oleh IOS (Kallapur \& Trombley, 2001). Rencana pengeluaran manjemen untuk masa depanserta pengeluaran manajemen saat masa sekarang diharapkan memiliki pengembalian yang lebih tinggi dari modal yang dikeluarkan oleh manajemen. Hal ini mempengaruhi nilai IOS perusahaan (Kole, 1991). Proksi dari IOS adalah Ratio Market to Book Value Equity (MBVE). IOS dapat diukur dengan:

MBVE $=\frac{\text { Jumlah Saham Beredar } \mathrm{x} \text { Closing Price }}{\text { Total Ekuitas }}$...

Struktur modal adalah pembelanjaan permanen dimana mencerminkan perimbangan antara utang jangka panjang dengan modal sendiri. Struktur modal dalam penelitian ini diproksikan dengan Debt Equity Ratio (DER), karena proksi 
tersebut mencerminkan sejauh mana modal perusahaan dapat membayar hutang kepada pihak luar. Selain itu DER juga menggambarkan proporsi suatu perusahaan dalam mendanai operasinya dengan menggunakan hutang. Rumus untuk mencari DER dapat digunakan perbandingan antara total utang dengan total ekuitas. Rumus mencari DER adalah sebagai berikut (Fajriana, 2016).

Debt to Equity Ratio $=\frac{\text { Total Debt }}{\text { Total Equity }} \times 100 \%$

Nilai perusahaan merupakan cerminan dari harga saham yang dimiliki oleh pasar melebihi nilai bukunya sehingga hal ini akan memberikan citra yang baik bagi perushaan. Nilai perusahaan merupakan persepsi investor terhadap tingkat keberhasilan perusahaan dalam mengelola sumber daya pada tahun berjalan. Rasio Tobin's $Q$ adalah proksi dari nilai perusahaan.

Pada BEI terdaftar banyak jenis perusahaan yang dikelompokkan berdasrkan sektor dan perusahaan yang dikelompokkan dalam sektor properti dan real estatedan telah terdaftar di BEI pada periode 2013-2017 dipilih sebagai populasi dalam penelitian ini. Dari seluruh perusahaan ini kemudian ditentukan sampel dengan menggunakan purposive sampling. Purposive samplingyaitu melakukan seleksi pada populasi untuk mendapatkan sampel dengan menggunakan kriteria tertentu dan didapatkan sampel sebanyak 28 perushaan untuk diteliti lebih lanjut.

Metode pengumpulan data yang digunakan dalam penelitian ini adalah studi pustaka dan studi dokumentasi. Studi pustaka adalah metode yang digunakan dengan memahami literature yang membuat pembahasan berkaitan dengan penelitian dengan mempelajari artikel, jurnal, buku, dan penelitian sebelumnya (Sugiyono, 2017: 476).Studi dokumentasi dilakukan dengan cara mengumpulkan laporan keuangan tahunan (annual report) perusahaan properti dan real estate yang terdaftar di Bursa Efek Indonesia (BEI) tahun 2013-2017 sesuai dengan kriteria sampel melalui website Bursa Efek Indonesia (BEI) www.idx.co.id, www.sahamok.com maupun website resmi masing-masing perusahaan.

Data kuantitatif dalam penelitian ini berupa laporan keuangan yang berisikan informasi mengenai komponen untuk mengukur investment opportunity set, struktur modal dan nilai perusahaan dan laporan tahunan yang berisikan komponen pengungkapan CSR. Data kualitatif berupa nama-nama perusahaan pada sektor perusahaan properti dan real estate.Data sekunder yang digunakan yaitu laporan tahunan dan laporankeuangan perusahaan properti dan real estate.

\section{HASIL DAN PEMBAHASAN}

Populasi penelitian yang digunakan adalah seluruh perusahaan pada sektorproperti dan real estate yang terdaftar di BEIperiode 2013-2017. Berdasarkan hasil pemilihan sampel dengan menggunakan metode purposive sampling, maka diperoleh jumlah perusahaan yang terpilih sebanyak 32sampel amatan. Berikut disajikan proses seleksi sampel seperti pada Tabel 1 sebagai berikut: 
Tabel 1. Proses Seleksi Sampel Penelitian

\begin{tabular}{clc}
\hline No & \multicolumn{1}{c}{ Kriteria } & $\begin{array}{c}\text { Jumlah } \\
\text { Perusahaan }\end{array}$ \\
\hline 1. & Perusahaan properti dan real estate yang terdaftar di BEI tahun & 48 \\
& $2013-2017$ & \\
2. & Perusahaan yang tidak mengungkapkan CSR secara konsisten & $(16)$ \\
& pada tahun 2013-2017 & 32 \\
& Jumlah sampel perusahaan properti dan real estate & $(4)$ \\
& Data outlier & 28 \\
& Jumlah data yang digunakan setelah outlier & 140 \\
Jumlah pengamatan (28 5 5 tahun)
\end{tabular}

Sumber : Data Penelitian, 2019

Berdasarkan Tabel 1 diperoleh sampel sebanyak 32 perusahaan properti dan real estate. Hasil pengolahan data mengidentifikasi adanya data outlier sebanyak 4 sampel, sehingga jumlah observasi data dalam penelitian ini menjadi 28 perusahaan properti dan real estate.

Deteksi terhadap univariate outlier dapat dilakukan dengan menentukan nilai batas yang akan dikategorikan sebagai data outlier yaitu dengan cara mengkonversi nilai data kedalam skor standardized atau z-score. Untuk sampel kecil (kurang dari 80), maka standar skor dinyatakan outlier jika nilainya $\geq 2,5$. Untuk sampel besar standar skor dinyatakan outlier apabila nilainya kisaran 3 sampai 4 (Ghozali \& Chairi., 2016).

Tabel 2. Analisis Statistik Deskriptif

\begin{tabular}{lcllll}
\hline Variabel & $\mathrm{N}$ & Minimum & Maximum & Mean & $\begin{array}{l}\text { Std. } \\
\text { Deviation }\end{array}$ \\
\hline CSR & 140 & 0,10 & 0,60 & 0,3082 & 0,11226 \\
MBVE & 140 & 0,09 & 4,77 & 1,1967 & 0,97335 \\
DER & 140 & 0,04 & 2,17 & 0,7822 & 0,52734 \\
TobinsQ & 140 & 0,12 & 2,66 & 1,0540 & 0,50681 \\
\hline
\end{tabular}

Sumber : Data Penelitian, 2019

Hasil dari uji deskriptif pada Tabel 2 menjabarkan mengenai nilai minimum, maksimum, mean dan juga std. deviation dari variabel-variabel yang digunakan dalam penelitian ini yaitu CSRI yang merupakan proksi dari pengungkapan CSR, MBVE yang merupakan proksi dari IOS, DER yang merupakan proksi dari struktur modal, TobinsQ yang merupakan proksi dari nilai perusahaan. Masing-masing nilai std. deviationdari tiap variabel memiliki nilai yang lebih kecil dari nilai mean masing-masing variabel. Hasil ini memiliki arti bahwa penyebaran data dari tiap variabel yang digunakan dalam penelitian ini tersebar secara normal yang berarti data yang digunakan tidak menyebabkan bias.

Tabel 3. Hasil Uji Normalitas

\begin{tabular}{lrr}
\hline & One-Sample Kolmogorov-Smirnov Test & \\
\hline & & $\begin{array}{c}\text { Unstandardized } \\
\text { Residual }\end{array}$ \\
\hline $\mathrm{N}$ & & 140 \\
Normal Parameters, $\mathrm{b}$ & Mean & .0000000 \\
& Std. Deviation & .84802970 \\
\hline Bersambung ... & &
\end{tabular}


Lanjutan Tabel 3.

\begin{tabular}{llr}
\hline Most Extreme Differences & Absolute & .076 \\
& Positive & .076 \\
& Negative & -.047 \\
Kolmogorov-Smirnov Z & & .897 \\
Asymp. Sig. (2-tailed) & & .397 \\
\hline
\end{tabular}

Sumber : Data Penelitian, 2019

Berdasarkan Tabel 3, nilai Asymp. Sig (2-tailed) adalah sebesar 0,397 yang lebih besar daripada 0,05. Hal ini berarti bahwa seluruh data pada model persamaan regresi dengan variabel dependen nilai perusahaan sudah berdistribusi secara normal.

\section{Tabel 4. Hasil Uji Multikolinearitas}

\begin{tabular}{lcc}
\hline \multicolumn{1}{c}{ Variabel } & Tolerance & VIF \\
\hline Pengungkapan CSR $\left(\mathrm{X}_{1}\right)$ & 0,917 & 1,091 \\
Investment Opportunity Set $\left(\mathrm{X}_{2}\right)$ & 0,952 & 1,050 \\
Struktur modal $\left(\mathrm{X}_{3}\right)$ & 0,953 & 1,049 \\
\hline
\end{tabular}

Sumber : Data Penelitian, 2019

Untuk terhindar dari masalah multikolinearitas variabel $\mathrm{X}_{1}, \mathrm{X}_{2}$, dan $\mathrm{X}_{3}$ perlu memiliki nilai tolerance yang melebihi sepuluh persen dan nilai VIF yang kurang dari 10. Setelah uji multikolinearitas dilakukan, variabe $X_{1}, X_{2}$, dan $X_{3}$ berhasil memiliki nilai tolerance yang melebihi sepuluh persen dan nilai VIF yang kurang dari 10. Hal ini menandakan bebasnya ketiga variabel bebas yang digunakan dalam penelitian dari gejala multikolinearitas.

Tabel 5. Hasil Uji Autokorelasi

\begin{tabular}{cccccc}
\hline No & $\mathrm{dl}$ & $\mathrm{Du}$ & $4-\mathrm{du}$ & $\mathrm{DW}$ & Simpulan \\
\hline 1 & 1,6804 & 1,7678 & 2,2322 & 1,995 & Bebas autokorelasi \\
\hline
\end{tabular}

Sumber : Data Penelitian, 2019

Agar terbebas dari gejala autokorelasi, nilai dw harus lebih kecil dari 4-du dan lebih besar dari du. Pada Tabel 5telah diperlihatkan hasil dari uji autokorelasi dimana nilai $\mathrm{dw}$ sebesar 1,995 merupakan lebih kecil dari 2,2322 dan lebih besar dari 1,7678. Hal ini menandakan bebasnya antar residual dari masalah autokorelasi.

Tabel 6. Hasil Uji Heterokedastisitas

\begin{tabular}{lcc}
\hline \multicolumn{1}{c}{ Variabel } & Sig. & Keterangan \\
\hline Pengungkapan CSR $\left(\mathrm{X}_{1}\right)$ & 0,773 & Bebas Heteroskedastisitas \\
Investment Opportunity Set $\left(\mathrm{X}_{2}\right)$ & 0,459 & Bebas Heteroskedastisitas \\
Struktur modal $\left(\mathrm{X}_{3}\right)$ & 0,268 & Bebas Heteroskedastisitas \\
\hline
\end{tabular}

Sumber :Data Penelitian, 2019

Berdasarkan Tabel 6 menunjukkan bahwa nilai signifikansi untuk variabel pengungkapan CSR $\left(\mathrm{X}_{1}\right)$ sebesar 0,773, untuk variabel Investment Opportunity Set $\left(\mathrm{X}_{2}\right)$ sebesar 0,459 dan untuk variabel struktur modal sebesar $\left(\mathrm{X}_{3}\right)$ 0,268, masing-masing lebih besar dari 0,05. Hal ini menunjukkan bahwamodel regresi bebas dari gejala heteroskedastisitas. 
Tabel 7. Hasil Analisis Regresi Linear Berganda

\begin{tabular}{llrrrrr}
\hline \multirow{2}{*}{ Model } & \multicolumn{2}{c}{$\begin{array}{c}\text { Unstandardized } \\
\text { Coefficients }\end{array}$} & \multicolumn{2}{c}{$\begin{array}{c}\text { Standardized } \\
\text { Coefficients }\end{array}$} & & \\
\cline { 2 - 4 } & \multicolumn{1}{c}{ B } & Std. Error & Beta & \multicolumn{1}{c}{. } & \multicolumn{1}{c}{ Sig. } \\
\hline 1 & (Constant) & .002 & .074 & & .031 & .975 \\
& CSR & .150 & .072 & .168 & 2.063 & .041 \\
& MBVE & .283 & .082 & .276 & 3.447 & .001 \\
& Struktur_Modal & .157 & .076 & .165 & 2.058 & .042 \\
\hline
\end{tabular}

Sumber: Data Penelitian, 2019

Hipotesis penelitian diuji dengan menggunakan analisis regresi linear berganda. Analisis ini digunakan untuk mengetahui besarnya pengaruh pengungkapan CSR yang diukur dengan Corporate Social Responsibility Index (CSRDI) $\left(\mathrm{X}_{1}\right)$, Investment Opportunity Set yang diproksikan dengan rasio Market to Book Value Equity $\left(\mathrm{X}_{2}\right)$, dan struktur modal yang di proksikan dengan Debt to Equity Ratio (DER) $\left(\mathrm{X}_{3}\right)$ pada Nilai perusahaan yang diproksikan dengan rasio penilaian Tobin's $Q(Y)$ di Perusahaan properti dan real estate yang terdaftar di Bursa Efek Indonesia dari tahun 2013-2017.Dari hasil analisis regresi linear berganda pada Tabel 7 dapat dibuat persamaan sebagai berikut:

$\mathrm{Y}=0,002+0,150 \mathrm{X} 1+0,283 \mathrm{X} 2+0,157 \mathrm{X} 3+\varepsilon$

Uji kelayakan model regresi bertujuan untuk mengetahui apakah semua variabel bebas yang diidentifikasi (Pengungkapan CSR, Investment Opportunity Set, dan Struktur Modal) tepat digunakan memprediksi Nilai perusahaan.

Tabel 8. Hasil Uji F

\begin{tabular}{llrrrrr}
\hline Model & & Sum of Squares & df & Mean Square & \multicolumn{1}{c}{ F } & \multicolumn{1}{c}{ Sig. } \\
\hline 1 & Regression & 20.644 & 3 & 6.881 & 9.362 & $.000^{\mathrm{a}}$ \\
& Residual & 99.962 & 136 & .735 & & \\
& Total & 120.606 & 139 & & & \\
& & & & &
\end{tabular}

Sumber : Data Penelitian, 2019

Pada Tabel 8 didapatkan hasil dari uji $\mathrm{F}$ adalah nilai $\mathrm{P}$ value bernilai lebih kecil dari nilai a yang telah ditentukan yaitu 0,05. Nilai sig. sebesar 0,000 menunjukan bahwa model yang digunakan dalam penelitian layak untuk digunakan.

Tabel 9. Hasil Uji Koefisien Determinasi

\begin{tabular}{lrrrr}
\hline Model & & & & \multicolumn{2}{c}{$\begin{array}{c}\text { Std. Error of the } \\
\text { Estimate }\end{array}$} \\
\hline 1 & $\mathrm{R}$ & R Square & Adjusted $R$ Square & .153 \\
\hline
\end{tabular}

Sumber : Data Penelitian, 2019

Nilai adjusted $\mathrm{R}^{2} \mathrm{yang}$ didapatkan setelah melakukan uji koefisien determinasi adalah 0,153. Nilai 0,153 memiliki arti sebesar 15,3 persen Pengungkapan CSR, IOS, serta Struktur Modalmempengaruhi variasi nilai perusahaan. Sisanya sebesar 84,7 persen dijelaskan oleh faktor-faktor lain yang tidak dijelaskan dalam model penelitian.

Pengaruh pengungkapan CSR pada nilai perusahaan $\left(\mathrm{H}_{1}\right)$. Berdasarkan hasil analisis pengaruh Pengungkapan CSR pada Nilai perusahaan pada Tabel 7diperoleh nilai signifikansi sebesar 0,041 dengan nilai koefisien regresi positif sebesar 0,150. Nilai signifikansi 0,041 <0,050 mengindikasikan bahwa $\mathrm{H}_{1}$ diterima. Hasil ini mempunyai arti bahwa Pengungkapan CSR berpengaruh positif pada nilai perusahaan. 
Pengaruh Investment Opportunity Set pada nilai perusahaan $\left(\mathrm{H}_{2}\right)$. Berdasarkan hasil analisis pengaruh Investment Opportunity SetpadaNilai perusahaandiperoleh nilai signifikansi sebesar 0,001 dengan nilai koefisien regresi positif sebesar 0,283. Nilai signifikansi 0,001<0,050 mengindikasikan bahwa $\mathrm{H}_{2}$ diterima. Hasil ini mempunyai arti bahwa Investment Opportunity Setberpengaruh positif padanilai perusahaan.

Pengaruh struktur modal pada nilai perusahaan $\left(\mathrm{H}_{3}\right)$. Berdasarkan hasil analisis pengaruh struktur modal pada Nilai perusahaan pada Tabel 7diperoleh nilai signifikansi sebesar 0,042 dengan nilai koefisien regresi positif sebesar 0,157. Nilai signifikansi 0,042 $<0,050$ mengindikasikan bahwa $\mathrm{H}_{3}$ diterima. Hasil ini mempunyai arti bahwa struktur modal berpengaruh positif pada nilai perusahaan.

Hasil analisis regresi menunjukan bahwa pengungkapan CSR secara statistik berpengaruh positif padanilai perusahaan $\left(\mathrm{H}_{1}\right.$ diterima).Penelitian ini sejalan dengan penelitian yang dilakukan oleh Permana \& Wirawati (2018)serta Bella \& Suaryana (2017) membuktikan bahwa pengungkapan corporate social responsibility berpengaruh positif pada nilai perusahaan.

Berdasarkan teori sinyal, semakin luas pengungkapan tanggung jawab sosial perusahaan, maka akan mampu meningkatkan daya tarik investor untuk dapat berinvestasi menanamkan saham kepada perusahaan dengan tingkat pengungkapan tanggung jawab sosial yang tinggi. Pasar akan dapat memberikan respon positif yang ditunjukkan dengan adanya peningkatan harga saham suatu perusahaan.

Hasil analisis regresi menunjukan bahwa Investment Opportunity Set secara statistik berpengaruh positif padanilai perusahaan $\left(\mathrm{H}_{2}\right.$ diterima), maka dapat disimpulkan bahwa IOS menunjukkan hubungan yang positif terhadap nilai perusahaan. Penelitian ini mendukung hasil penelitianSyardiana (2015)yang menyatakan bahwa IOS berpengaruh positif pada nilai perusahaan.Hasil ini memiliki arti bahwa pertambahan kekayaan atau aset pada perusahaan cenderung terjadi pada perusahaan yang melakukan banyak investasi. Kekayaan yang semakin bertambah memicu terjadinya perkembangan pada perusahaan kearah yang positif. perkembangan-perkembangan ini dilihat oleh investor sebagai sinyal yang baik. Investor telah memiliki pandangan yang positif pada perusahaan yang terus mengalami perkembangan sehingga berdampak pada banyaknya permintaan pada saham perusahaan tersebut. Banyaknya permintaan pada saham perusahaan kemudian akan berdampak pada naiknya harga saham yang berarti akan terjadi peningkatan pada nilai perusahaan.Kepercayaan investor terhadap perusahaan properti dan real estate yang memiliki keputusan investasi tinggi pada saat ini, menyebabkan kenaikan permintaan terhadap saham perusahaan.

Hasil analisis regresi menunjukan bahwa struktur modal secara statistik berpengaruh positif padanilai perusahaan $\left(\mathrm{H}_{3}\right.$ diterima).Penelitian ini sejalan dengan penelitian yang dilakukan oleh Chowdhury \& Chowdhury (2010) dan Indasari \& Yadnyana (2018) membuktikan bahwa struktur modal berpengaruh positif pada nilai perusahaan.

Terdapat kesesuaian antara teori sinyal dan hasil dari penelitian ini. Sinyal mengenai terjadinya peningkatan pada utang perusahaan mencerminkan 
keyakinan perusahaan akan prospek perusahaan di masa depan(Pratama \& Putu., 2016). Perusahaan yang sedang mengalami perkembangan tentunya memerlukan dana yang besar. Dana yang besar ini diperoleh dari salah satunya adalah utang. Utang yang diperoleh perusahaan dimanfaatkan untuk melakukan pengembangan pada bisnis perusahaan. Utang juga dapat digunakan perusahaan untuk menambah aset perusahaan. Perusahaan dengan jumlah aset yang banyak memberikan sinyal positif bagi investor.

\section{SIMPULAN}

Pengungkapan corporate social responsibility berpengaruh positif pada nilai perusahaan. Investment opportunity set berpengaruh positif pada nilai perusahaan.Struktur modal berpengaruh positif pada nilai perusahaan.

Pengukuran tingkat pengungkapan corporate social responsibility dalam penelitian ini menggunakan data dari laporan tahunan perusahaan karena perusahaan sektor properti dan real estate belum ada yang menerbitkan laporan keberlanjutan selama periode penelitian, sehingga sebagian besar item pengungkapan berdasarkan GRI G.4 tidak diungkapkan secara jelas. Penelitian selanjutnya dapat mempertimbangkan menggunakan perusahaan yang menerbitkan laporan keberlanjutan dan menggunakan data dari laporan keberlanjutan perusahaan dalam menganalisis pengungkapan corporate social responsibility serta dapat dilakukan pada sektor perusahaan yang lain diluar sektor properti dan real estate agar kesimpulan yang dihasilkan memiliki cakupan yang lebih luas.

Dalam memberikan penilaian terhadap suatu perusahaan sebaiknya juga memperhatikan faktor lain yang mempengaruhi nilai suatu perusahaan selain variabel dari variabel yang diteliti.

\section{REFERENSI}

Anjani, N., \& Astika, I. B. P. (2018). Pengaruh Pengungkapan Corporate Social Responsibility pada Nilai Perusahaan dengan Likuiditas Perusahaan sebagai Pemoderasi. E-Jurnal Akuntansi Universitas Udayana, 24(2), 889-928.

Antwi, S., Zhao, X., \& Mills, E. F. (2012). Capital Structure and Firm Value: Empirical Evidence from Ghana. International Journal of Business and Social Science, 103-111.

Asif, A., \& Aziz, B. (2016). Impact of Capital Structure on Firm Value Creation Evidence from the Cement Sector of Pakistan. International Journal of Research in Finance and Marketing, 6(6), 231-245.

Bella, L. K. G., \& Suaryana, I. G. N. A. (2017). Pengaruh IOS dan Pengungkapan CSR pada Nilai Perusahaan dengan Pertumbuhan Perusahaan Sebagai Variabel Pemoderasi. E-Jurnal Akuntansi Universitas Udayana, 19(1), 508-535.

Brigham, E. F., \& Housten, J. (2011). Dasar Dasar Manajemen Keuangan (11th ed.). Jakarta: Salemba Empat.

Chowdhury, A., \& Chowdhury, S. P. (2010). Impact of Capital Structure on Firm's Value: Evidence from Bangladesh. Business and Economic Horizons, 3(3), 111-122.

Cnnindonesia.com. (2017). Daya beli lemah indeks sektor properti melempem. Cuong, N. T. (2014). Threshold Effect of Capital Structure on Firm Value: 
Evidence from Seafood Processing Enterprise in the South Central Region of Vietnam. International Journal of Finance \& Banking Studies, 3(3), 14-29.

Dewi, A. S. M., \& Wirajaya, A. (2013). Pengaruh Struktur Modal, Profitabilitas dan Ukuran Perusahaan Pada Nilai Perusahaan. E-Jurnal Akuntansi Universitas Udayana, 4(2), 358-372.

Dewi, I. ., Siti, R. ., \& Nila, F. . (2014). Pengaruh Struktur Modal terhadap Nilai Perusahaan (Studi Pada Sektor Pertambangan yang ada di BEI Periode 20092012). Jurnal Administrasi Bisnis (JAB), 17(1), 1-9.

Fajriana, A. (2016). Pengaruh Corporate Social Responsibility, Keputusan Investasi, Dan Struktur Modal terhadap Nilai Perusahaan. Jurnal Nominal. Prodi Akuntansi Universitas Negeri Yogyakarta., 5(2), 16-28.

Fox, T., Ward, H., \& Howard. (2002). Public Sector Roles in Strengthening Corporate Social Responsibility: A Baseline Study, The World Bank.

Fuad, M. (2000). Pengantar Bisnis. Jakarta: PT. Gramedia Pustaka Utama.

Fumani, M. A., \& Moghadam, A. (2015). The Effect of Capital Structure on Firm Value, The Rate of Return on Equity and Earnings Per Share of Listed Companies in Tehran Stock Exchange. Research Journal of Finance and Accounting, 6(15), 50-57.

Ghozali, I., \& Chairi. (2016). Teori Akuntansi. Semarang: Badan Penerbit Universitas Diponegoro.

Hadi, N. (2011). Corporate Social Responsibility. Yogyakarta: Graha Ilmu.

Hamidah, G., \& Umdiana, N. (2017). Pengaruh Profitabilitas dan Investment Opportunity Set (IOS) terhadap Nilai Perusahaan dengan Harga Saham Sebagai Variabel Intervening. Jurnal Akuntansi Universitas Serang Raya, 3(2).

Hamidy, R. R., Wiksuana, I. G. B., Gede, L., \& Artini, S. (2015). Pengaruh Struktur Modal Dengan Profitabilitas Sebagai Variabel Intervening Pada Perusahaan Properti Dan Real Estate Di Bursa Efek Indonesia. Jurnal Ekonomi Dan BIsnis Universitas Udayana, 10, 665-682. https://doi.org/ISSN : 2337-3067

Hariyanto, M. S., \& Lestari, P. V. (2015). Pengaruh Struktur Kepemilikan, IOS, ROE terhadap Nilai Perusahaan pada Perusahaan Food and Beverage. EJurnal Manajemen Unud, 1599-1626.

Hermuningsih, S. (2013). Profitability, Growth Opportunity, Capital Structure, and The Firm Value. Jurnal Buletin Ekonomi Moneter Dan Perbankan,162(2), $128-148$.

Hidayah, N. (2015). Pengaruh Investment Opportunity Set (Ios) dan Kepemilikan Manajerial terhadap Nilai Perusahaan Pada Perusahaan Property dan Real Estat di Bursa Efek Indonesia. Jurnal Akuntansi, Fakultas Ekonomi Dan Bisnis Universitas Mercu Buana,19(3), 420-432.

Inastri, M. A., \& Mimba, N. P. S. H. (2017). Pengaruh Penerapan Good Corporate Governance dan Pengungkapan Corporate Social Responsibility pada Nilai Perusahaan. E-Jurnal Akuntansi Universitas Udayana, 21(2), 1400-1429.

Indasari, A. P., \& Yadnyana, I. K. (2018). Pengaruh Profitabilitas, Growth Opportunity, Likuiditas, dan Struktur Modal pada Nilai Perusahaan. EJurnal Akuntansi Universitas Udayana, 22(1), 714-746.

Investasi.kontan.co.id. (2013). Tren penurunan harga saham emiten properti.

Isaac, L. (2014). Corporate Capital Structure and Firm's Market Value in Nigeria. Research Journal of Finnance and Accounting,5(14), 16-3. 
Jitmaneeroj, B. (2018). A Latent Variable Analysis of Corporate Social Responsibility and Firm Value. Managerial Finance,44(4), 478-494.

Jogiyanto, H. (2007). Sistem Informasi Keprilakuan. Yogyakarta: Andi.

Kallapur, S., \& Trombley, M. A. (2001). The Investment Opportunity Set: Determinants, Consequences and Measurement. Managerial Finance, 27(3), 315.

Kebon, S. M. A. M., \& Suryanawa., I. K. (2017). Pengaruh Good Corporate Governance dan Investment Opportunity Set pada Nilai Perusahaan di Bursa Efek Indonesia. E-Jurnal Akuntansi Universitas Udayana, 20(2), 15341563.

Kole, S. (1991). An Investigation of The Building Of Compensation. Working Paper.

Li, D. (2017). Corporate Social Responsibility, Media Attention and Firm Value: Empirical Research On Chinese Manufacturing Firms. Collaborative Innovation Center of Resource-Conserving \& Environment-Friendly Society and Ecological Civilization, School of Business, Central South University, Changsha, 51(4), 1563-1577.

Lubis, I. L. (2017). Pengaruh Profitabilitas, Sruktur Modal, dan Likuiditas terhadap Nilai Perusahaan. Jurnal Aplikasi Bisnis Dan Manajemen, Institut Pertanian Bogor, 3(3), 458-465.

Myers, S. C. (1977). Determinants Of Corporate Stewart C. MYERS. Journal of Financial Economics.

Noerirawan, M. R., \& Muid, A. (2012). Pengaruh Faktor Internal dan Eksternal Perusahaan Terhadap Nilai Perusahaan. Diponegoro Journal of Accounting, 112.

Permana, I. B. T., \& Wirawati, N. G. P. (2018). Pengaruh Corporate Social Responsibility Disclosure pada Nilai Perusahaan dengan Kepemilikan Asing Sebagai Variabel Pemoderasi. E-Jurnal Akuntansi Universitas Udayana,25(1), 606-634.

Pratama, I. G. G. W., \& Putu., W. N. G. (2016). Pengaruh Struktur Modal dan Profitabilitas terhadap Nilai Perusahaan dengan Kepemilikan Manajerial Sebagai Pemoderasi. E-Jurnal Akuntansi Universitas Udayana,15(3).

Riaz, M., \& Qasim, M. (2016). Islamic microfinance Institution: The Capital Structure, Growth, Performance, and Value of The Firm in Pakistan. Journal of ISOSS, 2(1), 97-101.

Sari, N. (2017). Pengaruh Struktur Modal dan Kebijakan Hutang terhadap Nilai Perusahaan pada Perusahaan Manufaktur Sektor Tekstil dan Garmen Periode 2010-2014 di Bursa Efek Indonesia. Jurnal Jurusan Administrasi Bisnis Universitas Riau.

Sartono, A. (2012). Manajemen Keuangan Teori dan Aplikasi (4th ed.). Yogyakarta.: BPFE.

Senda, F. D. (2013). Pengaruh Kepemilikan Manajerial, Kepemilikan Institusional, Kebijakan Deviden, Profitabilitas, Leverage Financial, dan Investment Oppurtunity Set terhadap Nilai Perusahaan. Jurnal Manajemen Fakultas Ekonomi Universitas Diponegoro Semarang., 1-6.

Sihotang, E. (2018). Analisis Pengaruh Kinerja Keuangan terhadap Nilai Perusahaan dengan Pengungkapan Corporate Social Responsibilty (CSR) 
Sebagai Variabel Moderating (Studi Empiris pada Perusahaan Manufaktur yang Terdaftar di BEI pada Tahun 2014-2016). Jurnal Jurusan Akuntansi FEB UPR.

Situmeang, Y. L. M., \& Wiagustini, N. L. P. (2018). Pengaruh Struktur Modal terhadap Nilai Perusahaan dengan Kebijakan Hedging Sebagai Mediasi pada Perusahaan BUMN Go-Public. E-Jurnal Manajemen Fakultas Ekonomi Dan Bisnis Universitas Udayana., 7(3), 1368-1396.

Spence, M. (1973). Job Market Signaling. The Quarterly Journal of Economics, 87(3), 355-374.

Suweta, N. M. N. P. D., \& Dewi, M. R. (2016). Pengaruh Pertumbuhan Perjualan, Struktur Aktiva, dan Pertumbuhan Aktiva Terhadap Struktur Modal. EJurnal Manajemen Unud, 5(8), 5172-5199. https:/ / doi.org/ISSN : 2302-8912

Syardiana, G. (2015). Pengaruh Investment Opportunity Set, Struktur Modal, Pertumbuhan Perusahaan, dan Return On Asset Terhadap Nilai Perusahaan. Akuntabilitas UIN Syarif Hidayatullah, 8(1), 39-46.

Weston, J. F., \& Copeland., T. E. (2008). Dasar-Dasar Manajemen Keuangan. Jakarta: Erlangga.

Zeb, S., \& Rashid, A. (2016). Impact of Financial Health and Capital Structure on Firm's Value, with Moderating Role of Intangible Assets. Global Management Journal for Academic \& Corporate Studies, 6(1), 37-45. 